\title{
Examining the effect of intramammary infections with minor mastitis pathogens on the acquisition of new intramammary infections with major mastitis pathogens-A systematic review and meta-analysis
}

\author{
K. K. Reyher, ${ }^{*}{ }^{1}$ D. Haine, ${ }^{*} \neq$ I. R. Dohoo, ${ }^{*}+$ and C. W. Revie*† \\ ${ }^{*}$ Canadian Bovine Mastitis Research Network, C.P. 5000, St-Hyacinthe, Québec, J2S 7C6, Canada \\ †Centre for Veterinary Epidemiological Research, University of Prince Edward Island, Charlottetown, PEI, C1A 4P3, Canada \\ ‡Département de pathologie et microbiologie, Faculté de médecine vétérinaire, Université de Montréal, St-Hyacinthe, \\ Québec, C.P. 5000, J2S 7C6, Canada
}

\begin{abstract}
Major mastitis pathogens such as Staphylococcus aureus, Streptococcus agalactiae, Streptococcus uberis, Streptococcus dysgalactiae, and the coliforms are usually considered more virulent and damaging to the udder than minor mastitis pathogens such as Corynebacterium bovis and coagulase-negative staphylococci (CNS). The current literature contains several studies detailing analyses with conflicting results as to whether intramammary infection (IMI) with the minor pathogens decreases, increases, or has no effect on the risk of a quarter acquiring a new intramammary infection (NIMI) with a major pathogen. To investigate the available scientific evidence regarding the effect of IMI with minor pathogens on the acquisition of NIMI with major pathogens, a systematic review and meta-analysis were conducted. The total extant English- and Frenchlanguage literature in electronic databases was searched and all publications cited by relevant papers were investigated. Results from 68 studies were extracted from 38 relevant papers. Random-effects models were used to investigate the effects of CNS and $C$. bovis on acquisition of new IMI with any of the major pathogens, as well as individually for the minor pathogens and Staph. aureus. Significant heterogeneity among studies exists, some of which could be accounted for by using meta-regression. Overall, observational studies showed no effect, whereas challenge studies showed strong and significant protective effects, specifically when major pathogens were introduced into the mammary gland via methods bypassing the teat end. Underlying risk can account for several unmeasured factors, and studies with higher underlying risk found more protective effects of minor pathogens. Larger doses of challenge
\end{abstract}

Received April 4, 2012.

Accepted June 27, 2012

${ }^{1}$ Corresponding author: kreyher@upei.ca organisms reduced the protective effect of minor pathogens, and studies with more stringent diagnostic criteria for pathogen IMI identified less protection. Smaller studies (those utilizing fewer than 40 cows) also showed a greater protective effect than larger studies.

Key words: major pathogen, minor pathogen, protective effect, meta-analysis

\section{INTRODUCTION}

Major mastitis pathogens such as Staphylococcus aureus, Streptococcus agalactiae, Streptococcus uberis, Streptococcus dysgalactiae, and the coliforms are usually considered more virulent and damaging to the udder than minor mastitis pathogens such as Corynebacterium bovis and CNS. Studies conducted over the past 6 decades investigating the effects of minor pathogens on the risk of acquisition of major pathogen infections have yielded contradicting results (Green et al., 2002; Pyörälä and Taponen, 2009). Such studies vary widely in methodology. Experimental challenge studies involve inoculation of quarters with both minor and major pathogens or utilize natural infections with minor pathogens and experimentally induced infections with major pathogens. Infections have been introduced by intracisternal infusion, inoculation into the teat canal, or teat end exposure. Observational studies also exist that examine the interaction between natural infections with these 2 groups of pathogens in field settings.

Extreme heterogeneity exists among studies accounting for these interactions, and certain shortcomings of publications on this topic are recognized. Although a large number of mastitis pathogens exist in nature, only a few strains of pathogens are typically tested in laboratory settings. In addition, one of the roles of minor pathogens may be to prevent entry of major pathogens into the mammary gland, a situation that is certainly overcome by direct infusion of pathogens into the teat canal or cistern. Definition of an IMI provides some difficulty, as even mastitis experts are often in 
disagreement over how infection is defined (Andersen et al., 2010). Numerous issues may affect the interactions of minor and major pathogens within a quarter, cow, or herd. Differences such as anatomical features, immunological characteristics, previous infections, and other alterations in environment may play a role in susceptibility. Cow-level factors such as breed, season of calving, age, and stage of lactation may have an effect, and herd-level factors such as overall pathogen profile undoubtedly play a role, especially when random allocation of pathogens is not used. Studies that fail to account for these factors leave themselves open to a great number of confounding issues.

Narrative reviews bring together the diversity in results found in the literature (Pyörälä and Taponen, 2009; Pyörälä et al., 2011), and several papers have reviewed the effects of minor pathogen infections on acquisition of a major-pathogen new IMI (NIMI), either as a section of an all-encompassing literature review or in the introduction or discussion of a primary research article investigating such interactions. These reviews are helpful in summarizing some of what has been shown to date, but none exist that utilize a systematic or statistical methodology in the processes of identification of relevant studies, assessment of methodology and outcomes, and synthesis of the information covered. Many of the narrative reviews in the primary research literature focus on results similar to those obtained in the trial being described to support such results as having been previously identified. With such diversity in findings, however, support is almost always possible to some degree, even when the authors are citing trials conducted $50 \mathrm{yr}$ previous and involving only a handful of subjects. A systematic review, on the other hand, uses a transparent method to identify relevant literature, extract the required information, and summarize and synthesize the results of the included studies (Sargeant et al., 2006). Qualitative methods can be used to investigate the differences or similarities between studies, while quantitative methods seek to combine study results or investigate factors contributing to heterogeneity among studies. Because of the diverse publications and previous research concerning the effect of minor pathogens in bovine mastitis, a systematic review and meta-analysis was selected to shed further light on the information available on this topic. The objective of this paper was specifically to investigate the effect of minor pathogen IMI on the acquisition of a new major pathogen IMI in the bovine udder. Because substantial heterogeneity among studies was expected, the specific aim was to quantify and describe the sources of heterogeneity, rather than provide an overall estimate of the effect of minor pathogen IMI on major pathogen NIMI.

\section{MATERIALS AND METHODS}

\section{Literature Search}

An online literature search was conducted, consulting PubMed, CAB Abstracts, Agricola, and Google Scholar. To identify papers referring to minor pathogens, key words such as minor, Corynebacter*, and coagulasenegative staphylococc* were used. To include papers referencing major pathogens, the key words major, Staph* aureus, Staph* ${ }^{*}$ Strep *, and coliform * were used. These were then combined (using $A N D$ statements) with the keywords mastitis, risk, and protect* to identify studies investigating these interactions. Studies in English or French were considered and were drawn from peer-reviewed journals, conference proceedings, book chapters, and theses. Upon initial reading of salient articles by the primary author, works cited in those articles that appeared to deal with the interactions between minor and major pathogens were also retrieved.

Additionally, 19 investigators listed as authors on papers addressing this topic were contacted to identify any unpublished or difficult-to-locate studies related to the question of interest. Only one additional narrative review was identified by this route. Only manuscripts relating to mastitis pathogens of the bovine were included, and papers needed to deal specifically with IMI caused by minor pathogens (as opposed to teat apex colonization, for instance) and NIMI caused by major pathogens (as opposed to clinical mastitis without delineation of pathogen type, and so on).

\section{Data Extraction}

Three structured data collection forms (based on Sargeant et al., 2006) were devised and used for extraction of information. One form addressed general information given in the paper, the second included specific questions relating to the study type described, and the third form provided a structure for extraction of the outcomes and raw data given in the manuscripts. Two independent investigators read and extracted information simultaneously. The data extraction forms were initially tested on 5 included papers, and changes for clarity were addressed. Any differences in data extraction were discussed by the investigators, and consensus was reached after further referring to the paper in question. If a paper reported more than one set of observations for separate minor or major pathogens, each pairing of pathogens was reported separately. If a paper reported the effect of a minor pathogen on a combined group of major pathogens (e.g., CNS vs. Staph. aureus, Strep. uberis, and Strep. dysgalactiae), or when raw data were presented that allowed this group- 
ing to be performed, these data were also extracted independently. Although results from studies reporting by treatment groups (e.g., lactational therapy groups, postmilking teat disinfection trials) were recorded separately when details were provided in the manuscript, these were often combined in the meta-analysis due to inadequate group sizes for comparison.

Descriptive, study design, and study quality information extracted from each study are listed in Table 1. Challenge studies and observational studies also had individual information relevant to their study design extracted.

If presented in individual manuscripts, quarter-level data were used to construct $2 \times 2$ tables for use in the meta-analysis. These raw data were available for all but 2 papers detailing challenge experiments and all but 8 papers reporting observational findings. Four manuscripts presented odds ratios (OR), 1 unadjusted from a case-control analysis (Lam et al., 1997) and 3 adjusted from multilevel models (Schukken et al., 1999; Green et al., 2002, 2005), and either standard errors (SE) or 95\% confidence intervals, from which SE could be calculated. Three articles (Hogan et al., 1988; Woolford et al., 2001; Zadoks et al., 2001a) reported rates of new infections, and 3 others reported differing measures such as median difference of infection at the herd level (Michel et al., 2011), clinical differences (Spencer et al., 1968), and coefficients from Poisson models (Zadoks et al., 2001b). Data from these 6 papers could not be included in the meta-analysis, although, as selections for the systematic review, their reported outcomes are discussed later in this manuscript.

Several manuscripts presented results for multiple minor and major pathogens, so individual study values were constituted using the raw data or reported OR. Studies from observational papers representing several different data collections (e.g., on lactating cows vs. dry cows) were represented separately. Exceptions to this occurred when there appeared to be no substantial differences between the trials or when the researchers themselves combined data in the original publication. Many challenge studies reported differing pathogens and amounts of pathogens used in challenges; these data were extracted as separate studies when sufficient detail was reported.

\section{Meta-Analyses}

Several meta-analyses were carried out to investigate the effect of minor pathogen IMI on the acquisition of NIMI with major pathogens (Table 2):

- Manuscripts differed in the individual pathogens investigated, so a general meta-analysis compar- ing the effect of both minor pathogens (CNS and C. bovis) on acquisition of NIMI with any major pathogens (Staph. aureus, Strep. agalactiae, Strep. uberis, Strep. dysgalactiae, Escherichia coli, and other pathogens such as Klebsiella spp. or environmental streptococci) was initially performed.

- Studies were then grouped as observational or challenge studies and a meta-analysis within each group was performed.

- Separate meta-analyses investigating the effects of CNS and C. bovis individually on all major pathogens were also performed.

- The effects of each minor pathogen on acquisition of NIMI with Staph. aureus were also investigated in separate meta-analyses.

Because a high degree of heterogeneity was identified among studies, random-effects meta-analyses using the method described by DerSimonian and Laird (1986) were performed. Odds ratios were selected as the measure of association to incorporate the results of the 4 papers not containing raw data but reporting OR and SE or $95 \%$ CI. To calculate OR for those $2 \times 2$ tables with cells containing the value zero, an empirical continuity correction was used, as this is expected to decrease the amount of bias in estimation of effect in the subsequent meta-analyses (Sweeting et al., 2004).

\section{Meta-Regressions}

Meta-analysis regressions, or meta-regressions, were used to investigate the reasons for heterogeneity among studies. These analyses use data summarized at the study level to fit regression models with the natural log of the OR (lnOR) as the outcome variable.

First, all predictors described in Table 1 were investigated for their contribution to heterogeneity using univariable meta-regressions. Next, predictors of interest, as well as those showing association $(P \leq 0.05$ before Bonferroni correction) with the $\operatorname{lnOR}$, were combined in multivariable meta-regressions when the number of studies available made this possible. Finally, separate meta-regressions were fit for data sets involving any minor pathogen and any major pathogen, observational studies only, challenge studies only, CNS and major pathogens, C. bovis and major pathogens, CNS and Staph. aureus, and C. bovis and Staph. aureus.

Often such a small number of studies was included, especially in the individual CNS and $C$. bovis effects on Staph. aureus meta-regressions, that multivariable meta-regressions were not possible. Factors were initially combined with the 3-level study design variable and assessed for further significance. Those that appeared to provide much the same information as study 
Table 1. Descriptive, study design, and study quality information extracted from each of 68 studies included in the meta-analysis investigating the effect of CNS and Corynebacterium bovis IMI on acquisition of new IMI with major pathogens ${ }^{1}$

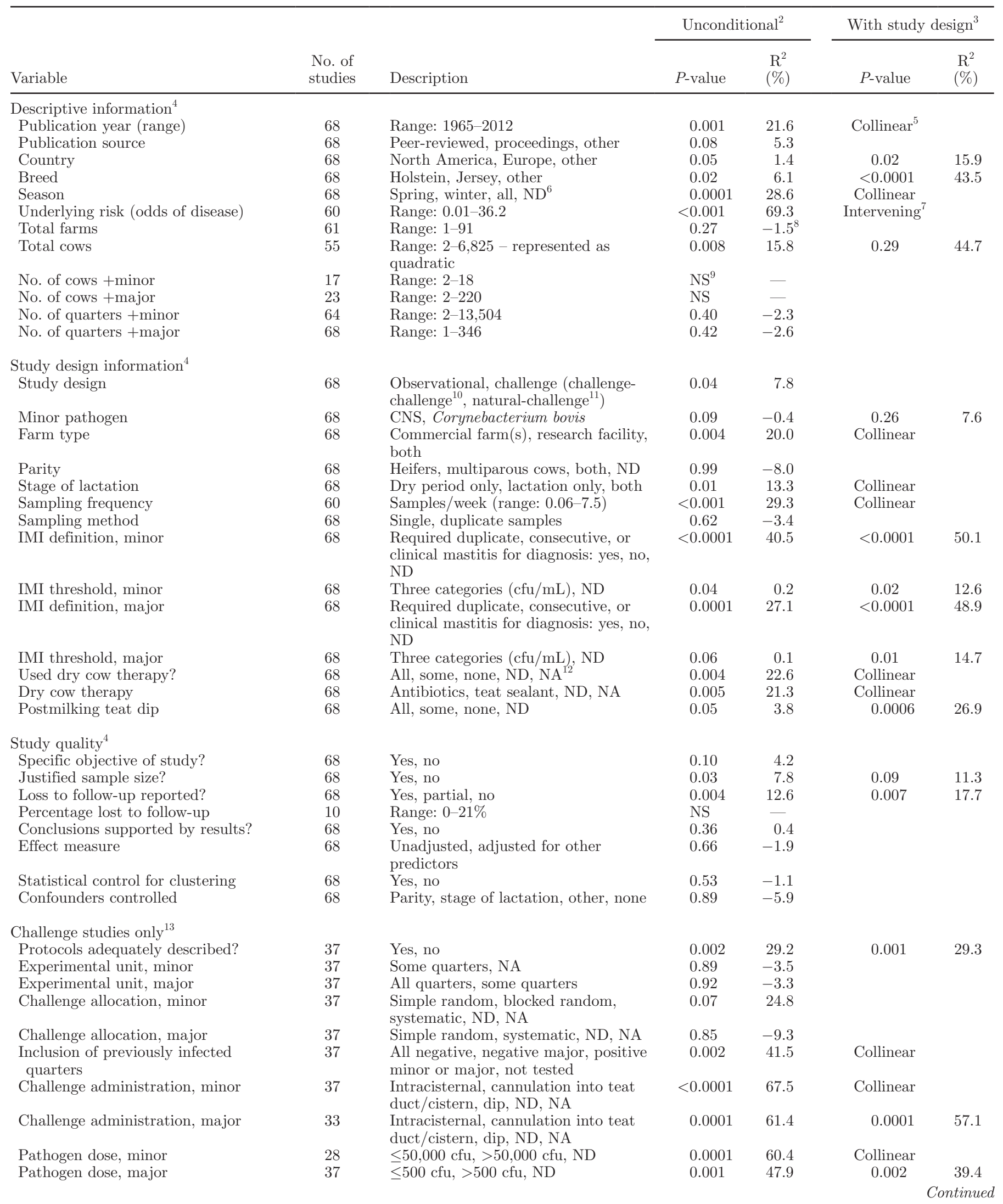


Table 1 (Continued). Descriptive, study design, and study quality information extracted from each of 68 studies included in the meta-analysis investigating the effect of CNS and Corynebacterium bovis IMI on acquisition of new IMI with major pathogens ${ }^{1}$

\begin{tabular}{|c|c|c|c|c|c|c|}
\hline Variable & $\begin{array}{l}\text { No. of } \\
\text { studies }\end{array}$ & Description & \multicolumn{2}{|c|}{ Unconditional $^{2}$} & \multicolumn{2}{|c|}{ With study design ${ }^{3}$} \\
\hline $\begin{array}{l}\text { Minor diagnosis to major challenge } \\
\text { interval }\end{array}$ & 33 & Range: $2-303 \mathrm{~d}$ & $<0.001$ & 60.7 & $<0.001$ & 60.5 \\
\hline Sufficient interval for diagnosis? & 37 & Yes, no, ND & 0.84 & -4.2 & & \\
\hline Farm selection & 31 & Convenience, purposive, random, ND & 0.40 & 5.4 & & \\
\hline Indicate farm reason to decline? & 31 & Indicated, not indicated, single farm & 0.28 & 4.9 & & \\
\hline Inclusion/exclusion criteria & 31 & Described, not described & 0.30 & 5.6 & & \\
\hline
\end{tabular}

${ }^{1}$ Both unconditional associations from univariable meta-regressions with major pathogen infection and the association observed after controlling for study design in multivariable meta-regressions are reported.

${ }^{2}$ Values provided for univariable meta-regression analyses with single predictor. Adjusted- $\mathrm{R}^{2}=$ value of heterogeneity between studies accounted for by this predictor [amount of variance $\left(\tau^{2}\right)$ accounted for by the model].

${ }^{3}$ Values provided for multivariable meta-regression analyses with predictor and 3-level variable for study design (only variables with unconditional $P$-values $\leq 0.05$ before Bonferroni correction were evaluated further). Adjusted- $\mathrm{R}^{2}=$ same as in footnote 2 .

${ }^{4}$ Thirty-four predictors evaluated, so $P$-values of unconditional associations $<0.0015$ would be considered significant using Bonferroni method for multiple comparisons.

${ }^{5}$ Variable represented much the same information as study design (collinear).

${ }^{6} \mathrm{ND}=$ not described.

${ }^{7}$ Variable causes the outcome but occurs between study design and the outcome (intervening).

${ }^{8} \mathrm{R}^{2}$ values $<0$ may occur when the predictor explains less variation than would be expected by chance (Harbord and Higgins, 2008).

${ }^{9}$ Reported by too few studies to give sensible values in meta-regression.

${ }^{10}$ Challenge studies where quarters were experimentally challenged both with a minor pathogen and subsequently with a major pathogen.

${ }^{11}$ Challenge studies where quarters were naturally infected with a minor pathogen and challenged with a major pathogen.

${ }^{12} \mathrm{NA}=$ not applicable.

${ }^{13}$ Sixteen predictors evaluated, so $P$-values of unconditional associations $<0.003$ would be considered significant using Bonferroni method for multiple comparisons.

${ }^{14}$ Four predictors evaluated, so $P$-values of unconditional associations $<0.01$ would be considered significant using Bonferroni method for multiple comparisons.

design (collinear) or were expected to be caused by study design (intervening) were not included in further modeling (Table 1). Multivariable models were then built using a manual stepwise procedure in an attempt to account for the most between-study heterogeneity while maintaining statistical significance $(P<0.05)$ in the predictors. Factors within the multivariable model were also assessed for collinearity to ensure they were not representing the same information. Adjusted- $\mathrm{R}^{2}$ values were used to indicate the relative reduction

Table 2. Estimated effects from separate meta-analyses of minor pathogen IMI on acquisition of new IMI with major pathogens ${ }^{1}$

\begin{tabular}{|c|c|c|c|c|c|}
\hline Analysis & $\begin{array}{l}\text { No. of } \\
\text { studies }\end{array}$ & $\begin{array}{l}\text { Odds } \\
\text { ratio }\end{array}$ & $95 \% \mathrm{CI}$ & $P$-value & $\tau^{2}$ \\
\hline Any minor pathogen/any major pathogen & 68 & 0.68 & $0.52,0.88$ & 0.003 & 0.65 \\
\hline Observational studies & 31 & 1.02 & $0.75,1.39$ & 0.89 & 0.46 \\
\hline Challenge-challenge studies ${ }^{2}$ & 28 & 0.31 & $0.15,0.66$ & 0.002 & 3.11 \\
\hline Natural-challenge studies ${ }^{3}$ & 9 & 0.38 & $0.22,0.67$ & 0.001 & 0.25 \\
\hline CNS/major pathogen & 33 & 0.52 & $0.35,0.77$ & 0.001 & 0.65 \\
\hline C. bovis/Staph. aureus & 16 & 0.57 & $0.34,0.94$ & 0.03 & 0.69 \\
\hline
\end{tabular}

${ }^{1} \tau^{2}=$ between-study variance or heterogeneity.

${ }^{2}$ Challenge studies where quarters were experimentally challenged with a minor pathogen and subsequently with a major pathogen.

${ }^{3}$ Challenge studies where quarters were naturally infected with a minor pathogen and challenged with a major pathogen. 


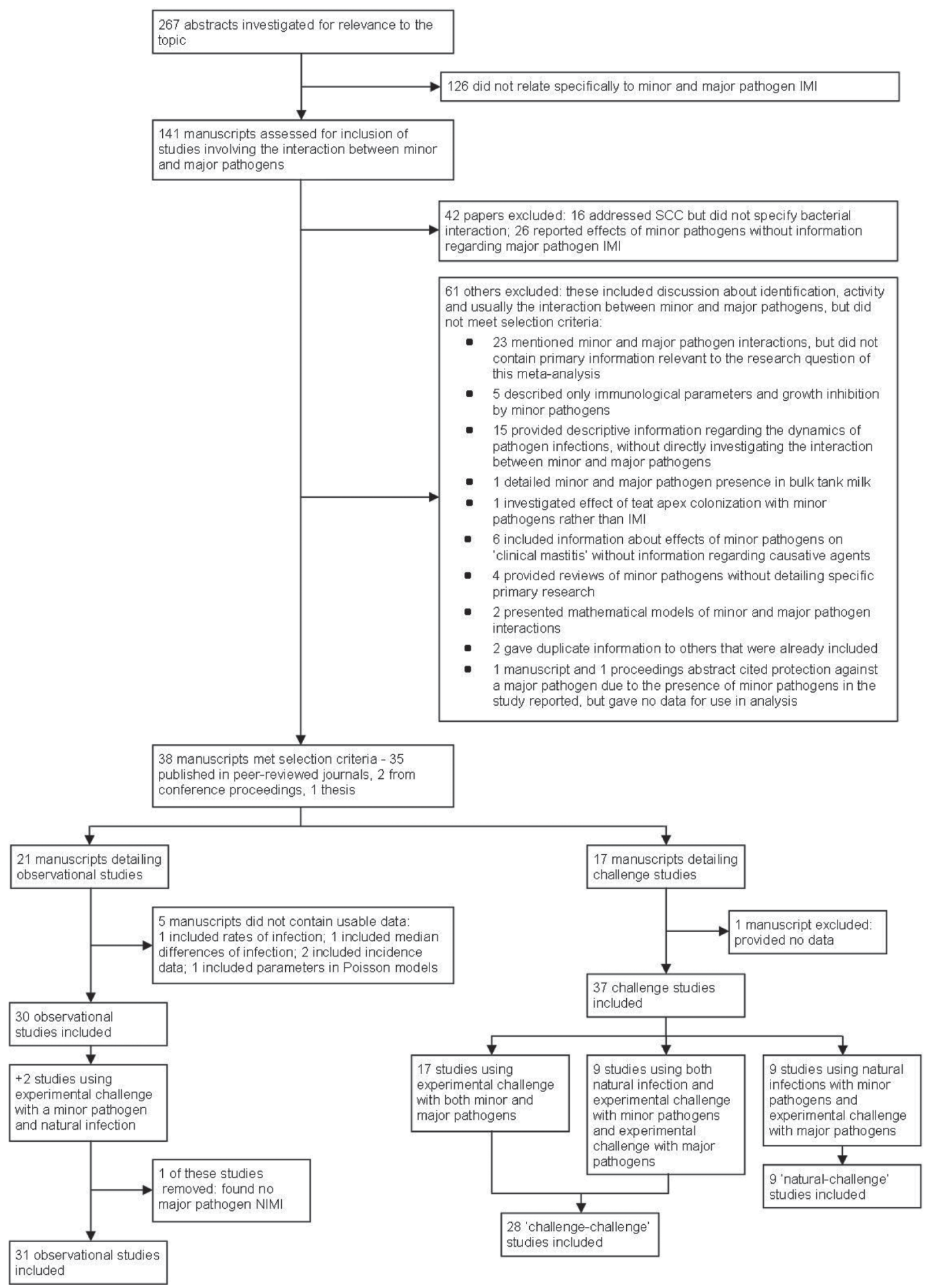

Figure 1. Flowchart detailing inclusion, exclusion, and categorization of manuscripts and studies included in the systematic review. Reasons for inclusion or exclusion are provided at each step of the systematic review. NIMI = new IMI.

in the between-study variance (Harbord and Higgins, 2008). To avoid type I errors occurring due to inclusion of multiple predictors in the multivariable meta-analy- ses, a random permutation test based on Monte Carlo simulation was used to provide a multiplicity adjustment of the $P$-values (Harbord and Higgins, 2008). To 
provide sufficient precision, the command was set to 20,000 permutations, and results were compared with those obtained in the multivariable models.

\section{Publication Bias or Small-Study Effects}

A funnel plot was generated to evaluate the presence of publication bias or small-study effects. This plot sets the OR against its SE, thereby displaying the differences among effects of smaller studies and those of larger studies (Harbord et al., 2009). Lack of symmetry in the plot indicates that bias may be present or that small studies with large standard errors may be influencing the estimate of the effect size. Egger's test for asymmetry was chosen from among the possible options and applied to evaluate the evidence for publication bias or small-study effects (Harbord et al., 2009). All analyses were conducted using Stata 12IC (StataCorp, College Station, TX).

\section{RESULTS}

\section{Literature Search}

The literature search identified 267 abstracts, which were further investigated for relevance to the topic. After removal of manuscripts that did not include information relating to infection with minor and major mastitis pathogens, did not specify bacteriological interaction, reported effects of minor pathogens without any information regarding major pathogen IMI, or did not directly address the specific question under investigation (Figure 1), 38 manuscripts containing the results of 69 studies met the selection criteria for inclusion in the meta-analysis (Appendix Table A1). Of these, 35 were published in peer-reviewed journals, 2 came from conference proceedings, and 1 was a thesis.

\section{Descriptive Information}

The papers included represented a wide range of research conducted over 6 decades in several countries. Descriptive information here is provided for all papers, and information related specifically to the studies included in the meta-analysis is listed in Table 1. Papers often contained several trials or observations about different minor and major pathogens. Manuscripts reported results of analyses involving what they termed CNS, coagulase-negative micrococci, or simply micrococci. These have been combined here and are referred to as CNS. Twenty-nine papers contained studies examining minor pathogen effects on NIMI with Staph. aureus (12 with CNS only, 11 with $C$. bovis, and 6 with both), whereas 13 papers contained studies with Strep. agalactiae as the outcome ( 6 with CNS, 6 with $C$. bovis, and 1 with both). Fifteen papers presented results of major infections with coliform bacteria ( 5 with CNS, 6 with $C$. bovis, 4 with both). Studies were conducted in the United Kingdom $(\mathrm{n}=9)$, United States $(\mathrm{n}=8)$, Sweden $(\mathrm{n}=5)$, Canada $(\mathrm{n}=5)$, France $(\mathrm{n}=3)$, the Netherlands $(\mathrm{n}=3)$, New Zealand $(\mathrm{n}=2)$, Denmark $(\mathrm{n}=1)$, Finland $(\mathrm{n}=1)$, and Switzerland $(\mathrm{n}=1)$. Holstein cattle were mainly used, followed by Jersey cattle and other dairy breeds (Swedish Red and White, Guernsey, Friesian, Meuse-Rhine-Yssel). The total number of cows was often small for challenge studies (median $=19$, mean $=64.5)$, although one multi-year challenge trial included 600 cows (Nickerson and Boddie, 1994), and papers often detailed the results of several challenge studies conducted on subsets of cows. Observational studies were much larger in terms of total cows $($ median $=255$, mean $=673.4)$. A variety of definitions for IMI was found among the papers, with diagnostic criteria from 20 to $350 \mathrm{cfu} / \mathrm{mL}$, and some papers required that IMI be present in consecutive samples, duplicate samples, or in samples from cows diagnosed with clinical mastitis to be considered infected. These were categorized into 4 variables, 2 each for minor and major pathogen definitions: a threshold category $(<100,100-299$, and $\geq 300 \mathrm{cfu} / \mathrm{mL})$ and a diagnosis classification (whether or not IMI needed to be diagnosed in consecutive, duplicate, or clinical mastitis samples). A subjective assessment of whether the conclusions of the authors were supported by the results presented in the paper was made by the data extractors.

All but one manuscript describing challenge experiments were included in the meta-analysis. Spencer et al. (1968) gave a general impression that no effect of minor pathogens was elicited, but did not report any data that were usable in further analyses. Of the remaining 16 papers reporting challenge experiments, 37 studies were compiled. Of these, challenge studies were separated into categories: "challenge-challenge" studies, where quarters were challenged with a minor pathogen and then challenged with a major pathogen ( $\mathrm{n}=17)$; "natural-challenge" studies, where quarters were naturally infected with minor pathogens before being challenged with major pathogens $(\mathrm{n}=9)$; and "both-challenge" studies, where some quarters were naturally infected with minor pathogens and some were challenged with the same minor pathogen (to increase numbers in the minor-pathogen IMI group), and then all were challenged with a major pathogen $(n=9)$ (Figure 1). Two studies included quarters challenged with a minor pathogen (CNS) and then observed for natural infection with a major pathogen (Pankey et al., 1985), but these were combined with the observational study 


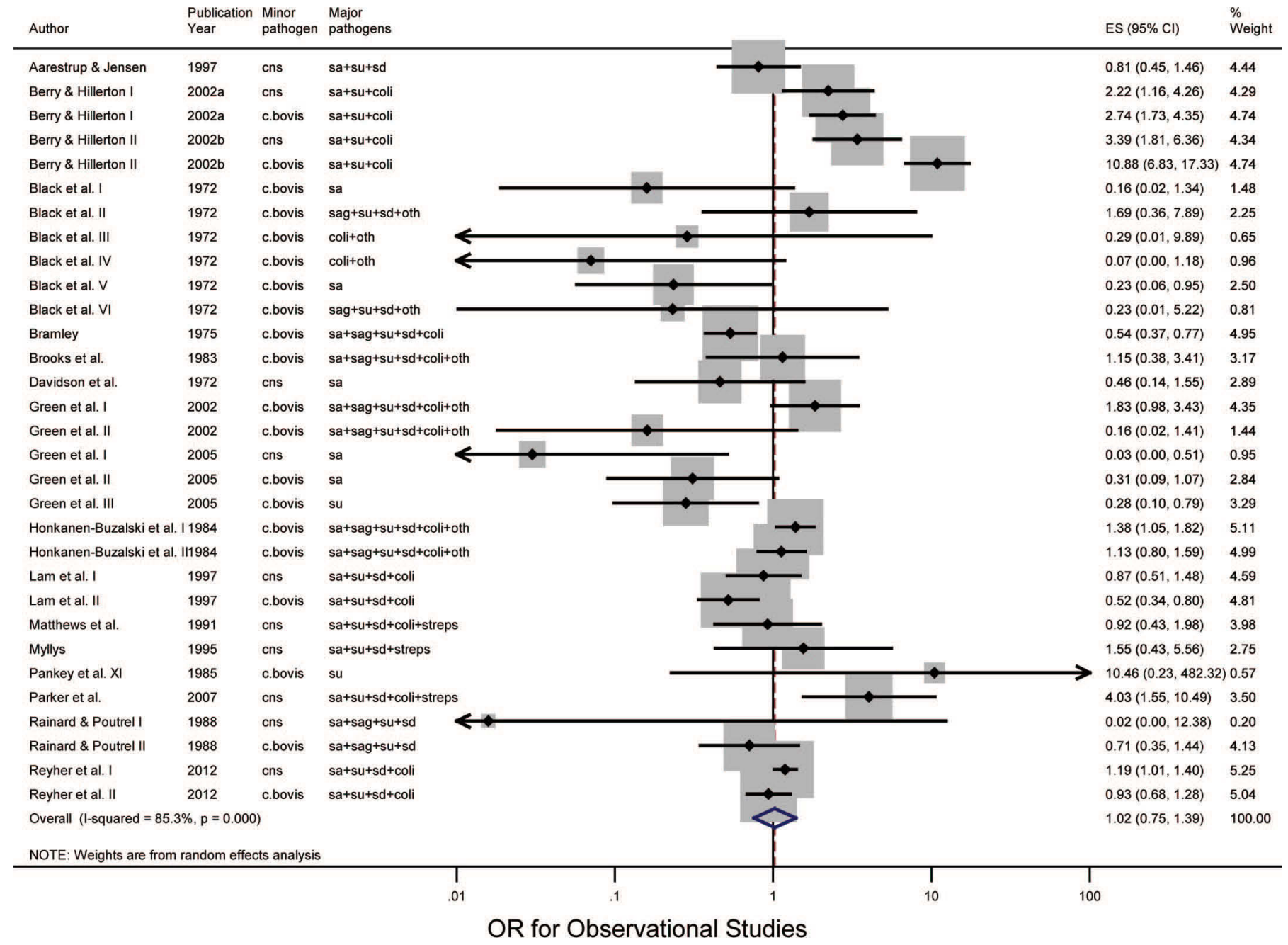

Figure 2. Forest plot displaying a random-effects meta-analysis of the effect of CNS and Corynebacterium bovis IMI on acquisition of new IMI with major pathogens for observational studies. Lengths of horizontal lines represent 95\% CI for the effect, black dots represent the individual odds ratio (OR) estimates of the studies, and gray squares are proportional to the weight given to each study. The dashed line represents the overall effect of all the studies $(\mathrm{OR}=1.02)$, whereas the solid line represents the value for no effect $(\mathrm{OR}=1)$. The diamond at the bottom of the dashed line represents the $95 \%$ CI for the overall effect of the observational studies $(0.75,1.39)$. Minor pathogens: CNS and Corynebacterium bovis; major pathogens: $\mathrm{sa}=$ Staphylococcus aureus, $\mathrm{su}=$ Streptococcus uberis, $\mathrm{sd}=$ Streptococcus dysgalactiae, coli $=$ coliforms, $\mathrm{sag}=$ Streptococcus agalactiae, oth $=$ other streptococci, Pseudomonas spp., yeast. $\mathrm{ES}=$ estimate of effect $=$ OR. Color version available in the online PDF.

group, because challenge with a major pathogen was believed to be the basis for an experimental challenge study (Figure 1). Twenty-two of the challenge studies involved CNS as the minor pathogen, and 15 challenge studies investigated the effects of $C$. bovis.

Of the 21 papers detailing observational work, 5 did not contain data that could be used in the metaanalysis (Figure 1). Hogan et al. (1988) reported rates of infection with minor and major pathogens, but extracting raw data from the information given was not possible. Michel et al. (2011) included only median differences of minor and major pathogen infections between herds and estimated a protective effect based on herd profile. Woolford et al. (2001) summarized a higher incidence of Strep. uberis infection in quarters infected with $C$. bovis, but did not provide any information with which to extract any further data. Zadoks et al. (2001b) reported a higher incidence of Strep. uberis in quarters infected with other pathogens (including minor pathogens) and also reported parameters in Poisson models (Zadoks et al., 2001a), but this information could not be transformed into a format useful for meta-analysis. The other 16 manuscripts comprised 31 usable individual studies. Of these, 11 reported on the effects of CNS, and 20 represented the effects of $C$. bovis IMI. 


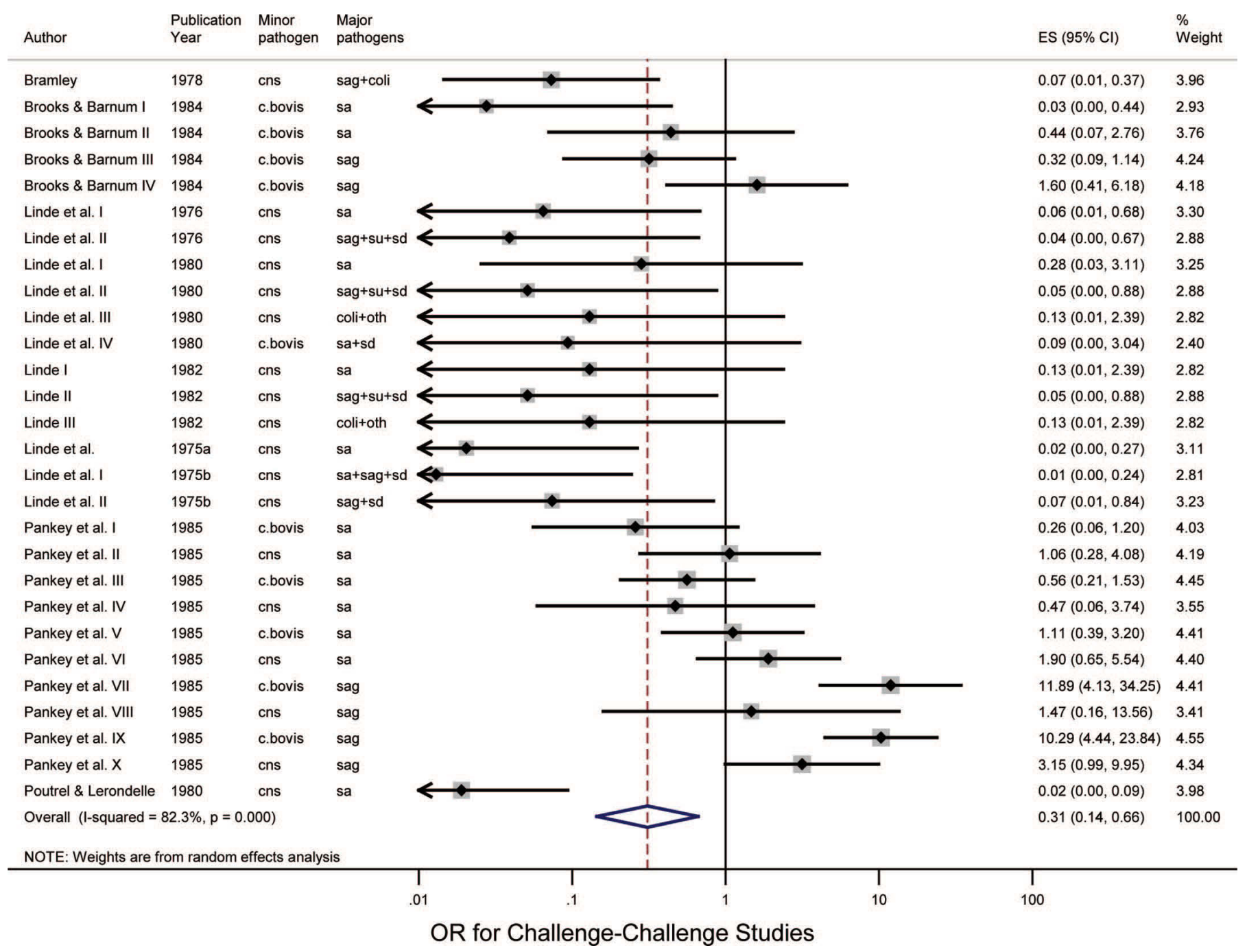

Figure 3. Forest plot displaying a random-effects meta-analysis of the effect of CNS and Corynebacterium bovis IMI on acquisition of new IMI with major pathogens for "challenge-challenge" studies. Lengths of horizontal lines represent $95 \%$ CI for the effect, black dots represent the individual odds ratio (OR) estimates of the studies, and gray squares are proportional to the weight given to each study. The dashed line represents the overall effect of all the challenge-challenge studies $(\mathrm{OR}=0.31)$, whereas the solid line represents the value for no effect $(\mathrm{OR}=$ 1 ). The diamond at the bottom of the dashed line represents the $95 \%$ CI for the overall effect of the challenge-challenge studies $(0.14,0.66)$. Minor pathogens: CNS and Corynebacterium bovis; major pathogens: $\mathrm{sa}=$ Staphylococcus aureus, $\mathrm{su}=$ Streptococcus uberis, $\mathrm{sd}=$ Streptococcus dysgalactiae, coli $=$ coliforms, $\mathrm{sag}=$ Streptococcus agalactiae, oth $=$ other streptococci, Pseudomonas spp., yeast. $\mathrm{ES}=$ estimate of effect $=$ OR. Color version available in the online PDF.

In total, 69 studies were extracted from the 38 manuscripts. One study failed to find any major pathogen NIMI and thus was not expected to contribute to the overall meta-analysis (Sweeting et al., 2004), so it was removed, leaving 68 usable studies (Figure 1).

\section{Meta-Analyses}

Because of the extreme heterogeneity among studies in these meta-analyses, the values obtained for the estimates of overall OR cannot be expected to accurately represent the effect of minor pathogen IMI on the acquisition of NIMI with major pathogens. Overall measures of effect are reported, but readers are cautioned that these overall measures may be of limited use due to the substantial differences among the studies included in these meta-analyses.

The estimated effects of minor pathogen IMI on acquisition of a major pathogen NIMI are given in Table 2 and are illustrated in forest plots in Figures 2, 3, and 4 (separated by type of study). A significant protective effect was seen for the effects of all minor pathogens on acquisition of NIMI with all major pathogens. Because study design was expected to be a major contributor to the heterogeneity among studies, it was broken down into sub-groups and analyzed separately. A significant 


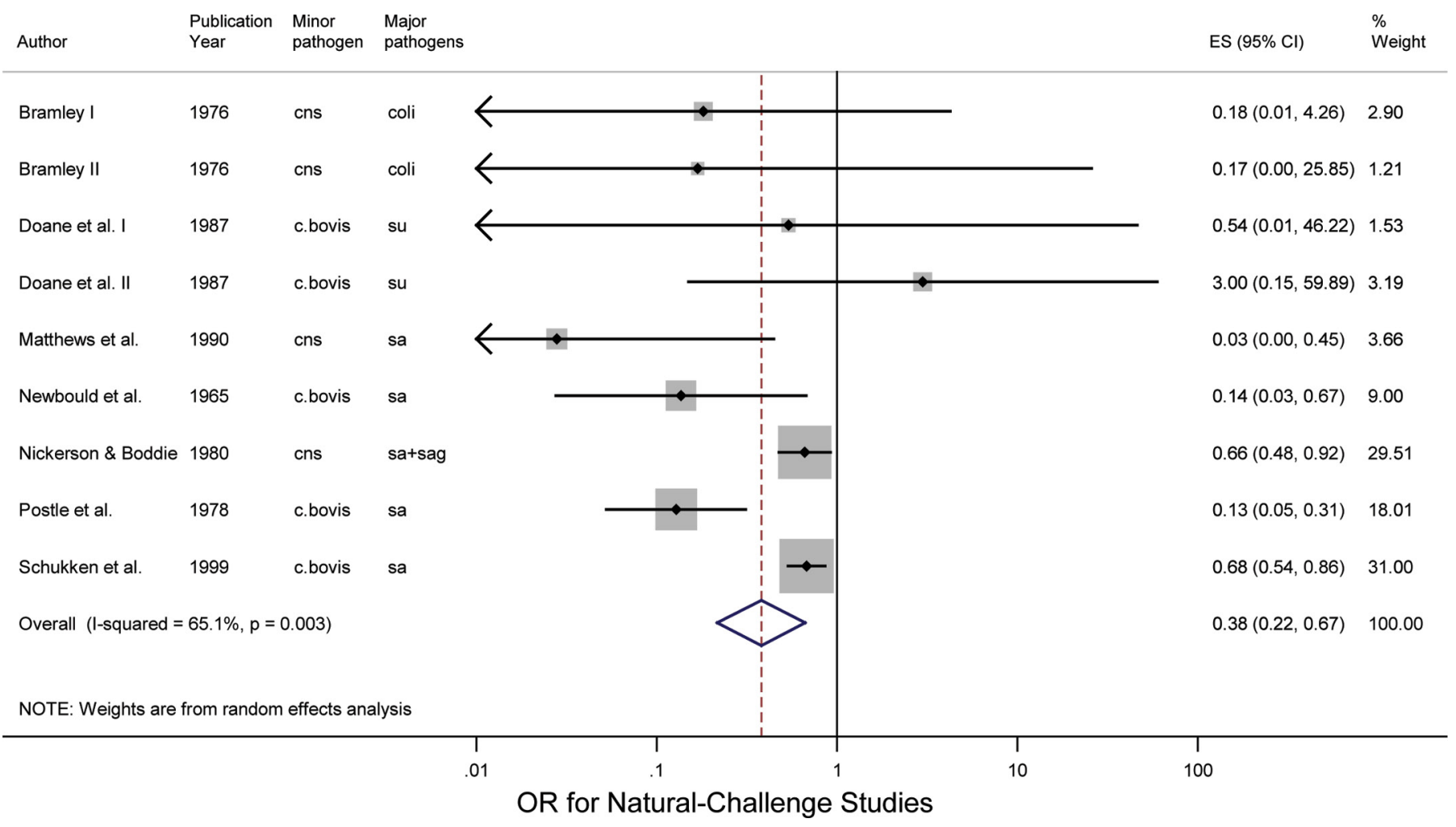

Figure 4. Forest plot displaying a random-effects meta-analysis of the effect of CNS and Corynebacterium bovis IMI on acquisition of new IMI with major pathogens for "natural-challenge" studies. Lengths of horizontal lines represent 95\% CI for the effect, black dots represent the individual odds ratio (OR) estimates of the studies, and gray squares are proportional to the weight given to each study. The dashed line represents the overall effect of all the natural-challenge studies $(\mathrm{OR}=0.38)$, whereas the solid line represents the value for no effect $(\mathrm{OR}=1)$. The diamond at the bottom of the dashed line represents the 95\% CI for the overall effect of the natural-challenge studies (0.22, 0.67). Minor pathogens: CNS and Corynebacterium bovis; major pathogens: $\mathrm{sa}=$ Staphylococcus aureus, $\mathrm{su}=$ Streptococcus uberis, coli $=$ coliforms, sag $=$ Streptococcus agalactiae. ES $=$ estimate of effect $=$ OR. Color version available in the online PDF.

protective effect was present in challenge studies; no effect was seen among observational studies (Table 2). Considerable between-study heterogeneity $\left(\tau^{2}\right)$ existed, most notably in the challenge-challenge studies (Table 2, Figure 3).

A sensitivity analysis was conducted on the full data set by removing studies individually and assessing change in effect. No one study was influential enough to alter the OR estimate from the statistically significant protective range (data not shown). Removal of all 12 studies by the research group of Linde and coworkers (Linde et al., 1975a,b, 1976, 1980; Linde, 1982), however, shifted the overall OR estimate to $0.84(95 \%$ CI: $0.65,1.10)$, a statistically nonsignificant effect $(P$ $=0.20)$.

\section{Meta-Regressions}

A specific aim of this research was to describe and quantify the heterogeneity among studies that exists in the literature in order to identify areas of difference that might explain the divergent effects of minor pathogens reported through the years. Univariable meta-regressions revealed that several predictors had significant influence on the OR estimates, even when a Bonferroni correction was applied (Table 1).

Minor Pathogens and Study Design. Little evidence was found of the presence of either CNS or $C$. bovis contributing to the heterogeneity in OR among studies in the data set including both minor pathogens $\left(P=0.09\right.$, adjusted- $\left.\mathrm{R}^{2}=-0.4 \%\right)$; therefore, this variable was not included in further multivariable meta-regressions. Overall, OR in challenge studies were significantly lower than those found in observational studies $(P=0.01)$. To further delineate the nature of this relationship, the categories of challenge studies were separated; this increased the $\mathrm{R}^{2}$ to $37.9 \%$, and showed that the majority of the difference in effect came from the both-challenge studies, those where quarters were challenged with minor pathogens or could be naturally infected with minor pathogens before major pathogen challenge. Studies in the both-challenge category were significantly more likely to show a protective effect of minor pathogens $(P<0.001)$ compared with obser- 
vational studies; compared with no effect $(\mathrm{OR}=1)$, both-challenge studies were more likely to show substantial protection $(\mathrm{OR}=0.06)$. Studies in the naturalchallenge category were also significantly more likely to show protection $(P=0.04$, protection of $\mathrm{OR}=0.33$ compared with no effect), whereas the OR of challengechallenge studies were not predicted to be significantly different from those generated by observational studies. Ten of the 11 studies in the both-challenge group were conducted by one research group (Linde and coworkers), however, and the overall methods of this research group were believed to account for the majority of these differences. Because all of these studies had animals that were challenged with a minor pathogen, these 11 both-challenge studies were combined with the challenge-challenge group to form a 3-level categorical variable for study design (observational, challenge-challenge, and natural-challenge). As this set of variables was believed to confound the relationship between the outcome and several other predictors in the analyses, this representation of study design was forced into all multivariable meta-regression models.

Underlying Risk. Underlying risk refers to risk of the outcome (here, a NIMI with a major pathogen) in the population of bovine quarters not infected with minor pathogens, and accounts for several unmeasured variables in a population. Significant variation was found in the underlying risk among studies - 48 different values ranging from an odds of 0.01 to 36.2 were calculated - and underlying risk was a significant predictor in unconditional analysis. Because underlying risk is inherently related to the OR, the use of metaregression alone for evaluation of its contribution to heterogeneity is not adequate (Dohoo et al., 2007). To further evaluate the effect of heterogeneity due to underlying risk, a recommended maximum likelihood random-slopes model was fit and compared with the outcomes from standard meta-regression. This model resulted in a coefficient estimate $(\boldsymbol{\beta})$ very close to the value of $\beta$ estimated by standard meta-regression $(\beta=$ $-0.45, \mathrm{SE}=0.06$ in recommended model, $\beta=-0.50$, $\mathrm{SE}=0.06$ in meta-regression). Because this value was in close agreement and was not much less than zero, the bias in estimation of the outcome and of $\beta$ by standard tools was assumed to be small, and the use of standard meta-regression was deemed sufficient (Dohoo et al., 2007).

As underlying risk in a study increased, the amount of protection due to minor pathogens estimated by that study also increased. Underlying risk was seen to be much lower in observational studies (mean odds of major pathogen NIMI in quarters not infected with minor pathogens $=1.8$ ) as opposed to challenge-challenge studies (mean odds $=4.5$ ) or natural-challenge stud- ies $($ mean odds $=10.0)$. Underlying risk was not significantly associated with the outcome in observational studies. Underlying risk was a significant predictor in challenge studies, however, with a similar level of effect in both challenge-challenge and natural-challenge studies.

Unconditional Analyses of Other Factors. Several study-level factors proved to be significant predictors of the heterogeneity among studies in unconditional analyses. Because of the multiple comparisons made, Bonferroni correction should be applied to decrease type I error, and $P$-values were divided by 34 to evaluate significance (only factors with $P$-values $<0.0015$ would be considered statistically significant). Several predictors would have been significant after Bonferroni correction or were close enough to significance to be of specific interest. Table 1 provides an overview of the factors investigated, their unconditional associations with the outcome, and the amount of variation explained by each factor.

Briefly, the odds of a study finding an increased risk of major pathogen NIMI caused by minor pathogen IMI increased through the years, and the season in which the study took place was significant, although the major difference was among studies performed over all 4 seasons and those that did not declare in which season they were performed (mainly short trials). These shorter studies were more likely to find a protective effect of minor pathogens than were studies conducted over a longer period. Studies conducted on a combination of research and commercial farms found significantly more risk of minor pathogen IMI than studies conducted on commercial farms, and no significant differences were observed among studies conducted on research farms and those conducted on commercial operations $(P=$ 0.07 ), although a trend was found for studies on research facilities to detect protection. Studies that took samples more often were more likely to find a protective effect of minor pathogens. Requiring that minor or major pathogen IMI be found in duplicate samples, consecutive samples, or in samples from cows diagnosed with clinical mastitis (a more stringent requirement for IMI diagnosis than just finding it in single samples) was associated with an increased likelihood of identifying minor pathogen IMI as risk factors. Studies that failed to report loss of study subjects to follow-up were also more likely to find increased risk associated with minor pathogen IMI than were studies that did report loss to follow-up $(P=0.001)$.

Multivariable Model. Eighteen of the 34 factors assessed by unconditional analyses had $P \leq 0.05$ before Bonferroni correction, and so were investigated further in multivariable meta-regressions (Table 1). A multivariable model with study design, minor pathogen 
Table 3. Multivariable meta-regression model to explain heterogeneity ${ }^{1}$ among 68 studies on the effect of minor pathogen IMI on acquisition of new IMI with major pathogens

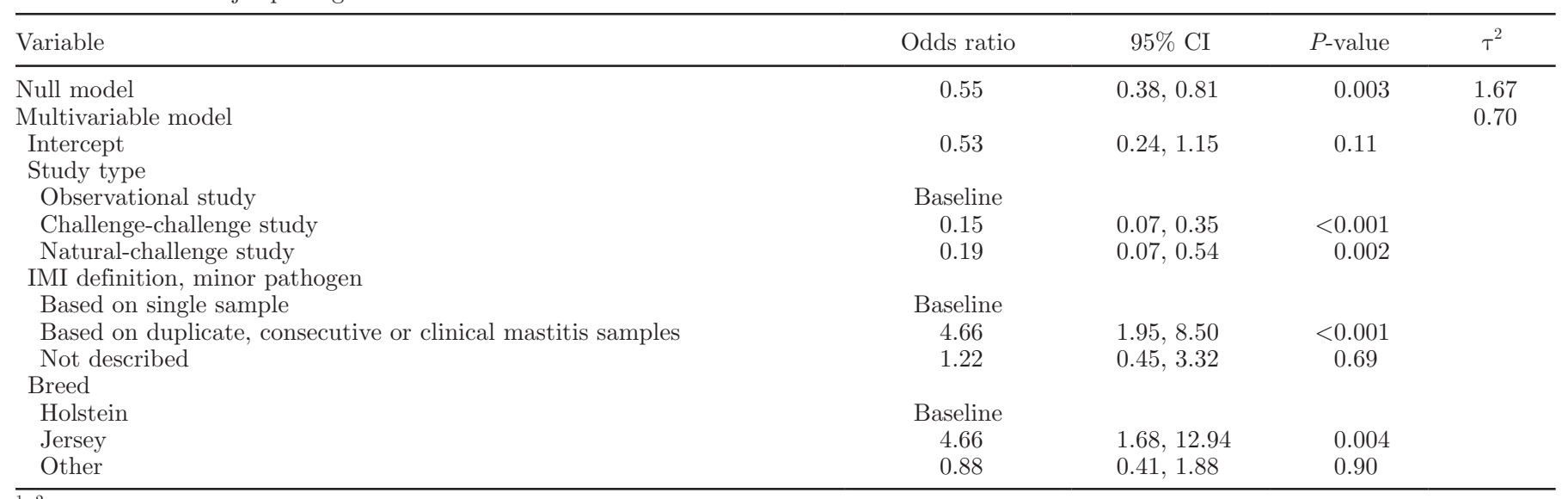

${ }^{1} \tau^{2}=$ between-study variance or heterogeneity.

IMI definition, and breed was built, which explained $58.0 \%$ of the between-study heterogeneity $\left(\tau^{2}\right.$ reduced from 1.67 to 0.70 ; Table 3). Challenge-challenge studies were significantly more likely to find protection than observational studies, as were natural-challenge studies. Studies where minor pathogen IMI was only diagnosed if the minor pathogen appeared in duplicate samples, consecutive samples, or in samples from quarters with clinical mastitis (as opposed to single samples) were significantly more likely to show an increased risk of major pathogen NIMI by minor pathogen IMI. A similar effect was also seen for studies in which major pathogen NIMI was stringently defined, but these 2 variables were very collinear and the effect was greater for minor pathogens, so the minor pathogen variable was included in the multivariable model. To avoid type I errors occurring due to inclusion of multiple predictors in the multivariable meta-analysis, a random permutation test based on Monte Carlo simulation was used to provide a multiplicity adjustment of the $P$-values (Harbord and Higgins, 2008). To provide sufficient precision, the command was set to 20,000 permutations and results were compared with those obtained in the multivariable model. Challenge-challenge and naturalchallenge studies remained significantly different from observational studies $(P=0.001$ and $P=0.04$, respectively), and diagnosis of minor pathogen IMI requiring duplicate, consecutive, or clinical mastitis was still significantly different from diagnosis on single samples alone $(P=0.009)$. The $P$-value for the increased risk for studies conducted on Jerseys compared with Holsteins became borderline significant $(P=0.07)$.

Underlying risk was not included in the above model because it was believed to be an intervening variable, coming between the role of study design and the outcome (lnOR) on the causal pathway. To build a model representing the role study design played, therefore, underlying risk could not be included. Underlying risk was, however, believed to account for much of the heterogeneity in the outcome, so adding it to a multivariable model was of interest. Study design also needed to be included in such a model, because it was believed to have a confounding effect on the underlying risk. Another multivariable model was built including underlying risk, therefore, that was able to account for $81.7 \%$ of heterogeneity among studies (data not shown). This model was similar to the model presented in Table 3 , but breed was found to be associated with underlying risk in simple linear regression, so was not included. The true effect of study design was obscured in this model, although the effect of minor pathogen IMI diagnosis was relatively unchanged. This model revealed that, as the risk of a major pathogen NIMI in quarters not infected with a minor pathogen increased, the odds of such a study identifying overall risk for major pathogen NIMI decreased (i.e., studies with higher underlying risk found more protective effects of minor pathogens; OR 0.61 compared with no effect, $P<0.001$ ).

Factors Specific to Observational and Challenge Studies. Because of their intrinsic differences, certain factors relating specifically to challenge studies and observational studies were evaluated separately. Studies where cows were housed in conditions similar to those in the field were more likely to identify risk caused by minor pathogens than those that did not describe housing conditions, but this result was not significant when a Bonferroni correction was applied, nor was it significant in further multivariable model building. This indicates that differences among observational studies can be mostly explained by factors that were common to both observational and challenge studies (Table 1). Several exclusive predictors were significant 


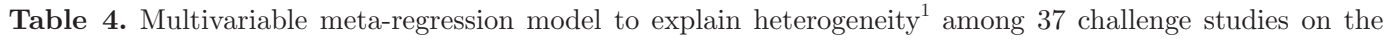
effect of minor pathogen IMI on acquisition of new IMI with major pathogens

\begin{tabular}{|c|c|c|c|c|}
\hline Variable & Odds ratio & $95 \% \mathrm{CI}$ & $P$-value & $\tau^{2}$ \\
\hline Null model & 0.32 & $0.17,0.59$ & 0.001 & 2.34 \\
\hline \multirow{2}{*}{\multicolumn{5}{|c|}{$\begin{array}{l}\text { Multivariable model } \\
\text { Intercept }\end{array}$}} \\
\hline & 0.20 & $0.08,0.54$ & 0.002 & \\
\hline \multicolumn{5}{|l|}{ Study type } \\
\hline Challenge-challenge study & Baseline & & & \\
\hline Natural-challenge study & 1.31 & $0.41,4.18$ & 0.64 & \\
\hline \multicolumn{5}{|c|}{ Dose of major pathogen administered } \\
\hline$\leq 500 \mathrm{cfu} / \mathrm{mL}$ & Baseline & & & \\
\hline$>500 \mathrm{cfu} / \mathrm{mL}$ & 3.71 & $1.27,10.91$ & 0.02 & \\
\hline Not described & 11.94 & $3.25,44.26$ & 0.001 & \\
\hline \multicolumn{5}{|c|}{ Description of challenge protocols } \\
\hline Adequately described & Baseline & & & \\
\hline Inadequately described & 0.15 & $0.05,0.44$ & 0.001 & \\
\hline
\end{tabular}

for challenge studies, however, and in unconditional analyses appeared to explain a significant portion of the heterogeneity among studies. Studies that included cows naturally infected with minor pathogens in challenge studies were more likely to identify a protective effect of minor pathogens than studies using uninfected cows $(P<0.001)$. Studies that did not report whether they tested cows before major pathogen challenge were also more likely to find a protective effect of minor pathogens $(P=0.03)$. Route of administration of minor and major pathogens was also significantly associated with the outcome. Studies where minor or major pathogens were administered via immersion of the teat in an infective broth (teat dip) reported less protection than those involving direct infusion of minor pathogens into the teat (intracisternal injection or cannulation into the teat cistern or teat duct; $P<0.001$ ). As the interval between minor pathogen diagnosis and major pathogen challenge increased, the amount of protection afforded by minor pathogen IMI decreased $(P<0.001)$.

Predictors that were significant $(P \leq 0.05)$ in unconditional analyses (before Bonferroni correction) were evaluated for collinearity with study design using tabulation for categorical predictors and simple linear regression for continuous predictors. All predictors that were not collinear with study design retained their significance (Table 1). These predictors were evaluated for collinearity with one another, and then entered into multivariable models in a stepwise fashion to achieve a maximum $\mathrm{R}^{2}$ while maintaining statistical significance for the predictors. A model explaining $66.3 \%$ of the heterogeneity between studies resulted, which contained study design, major pathogen dose, and whether or not a study adequately reported the challenge protocols (Table 4). Study design was not significant in unconditional analyses among challenge studies, nor was it significant in the multivariable model. In studies utilizing major pathogen doses $>500 \mathrm{cfu} / \mathrm{mL}$, the amount of protection afforded by minor pathogen IMI was decreased (lnOR increased). Studies that did not report the dose of major pathogen used in experimental challenge also showed a decreased amount of protection compared with studies that used the smaller dose. Studies that did not adequately report challenge protocols were all smaller ( $<40$ cows) and showed an overall more protective effect of minor pathogens on acquisition of NIMI with major pathogens (lnOR decreased). The random permutation multiplicity adjustment was also applied to this model at a setting of 20,000 permutations, and the $P$-value for the reporting of challenge protocols remained significant $(P=0.02)$, as did the difference seen

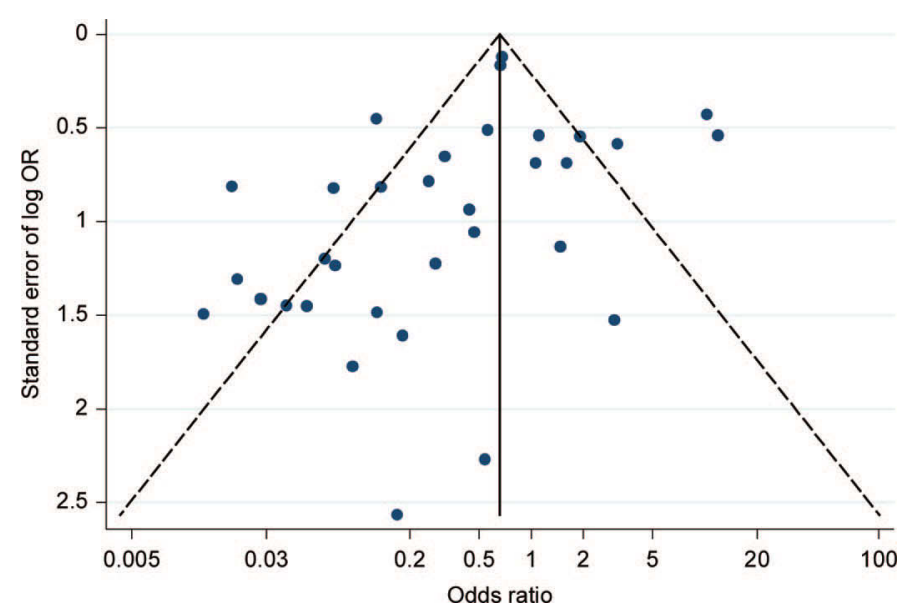

Figure 5. Funnel plot of the individual study odds ratio (OR) estimates for the effect of CNS and Corynebacterium bovis IMI on acquisition of new IMI with major pathogens for challenge studies. Small-study effects are evidenced by the presence of numerous studies with small OR (x-axis) and large standard errors (y-axis) on the left hand side of the plot. Color version available in the online PDF. 
between nonreporting of major pathogen challenge dose versus the lower dose $(P=0.005)$.

Data Subsets. Many of the same factors were significant in meta-regressions for the data subsets (CNS and all major pathogens, C. bovis and all major pathogens, CNS and Staph. aureus, C. bovis and Staph. aureus), although it was more difficult to build multivariable meta-regression models for these subsets due to the smaller numbers of studies. Of note was that the threshold for diagnosis with either a minor pathogen or major pathogen was a significant predictor of the outcome in the data subset for CNS with all major pathogens, even when modeled with study design. These 2 variables accounted for $44.0 \%$ of the heterogeneity between studies. Similar to previous results, challenge studies showed more protection than observational studies. Studies that used a liberal diagnosis for IMI or NIMI $(<100$ $\mathrm{cfu} / \mathrm{mL}$ ) were more likely to identify a protective effect of minor pathogens (OR decreased to 0.30 compared with no effect, $P=0.08$ ) than those using $\geq 100 \mathrm{cfu} /$ $\mathrm{mL}$, as were studies that did not specify the threshold used for diagnosis with IMI (OR decreased to 0.18 compared with no effect, $P=0.01)$.

\section{Publication Bias or Small-Study Effects}

Funnel plots were generated and used to visually assess the evidence for publication bias or small-study effects (Figure 5). Study size (and therefore study SE) was confounded by study type, so observational studies and challenge studies were assessed separately. The graph for observational studies looked roughly symmetrical (data not shown), and the Egger's test for funnel plot asymmetry gave little evidence for small-study effects $(P=0.31)$. Challenge studies, however, were distributed more on the left side of the graph (Figure 5 ), with 2 small studies showing protective effects of minor pathogens and large standard errors being evident in the left lower quadrant. No small studies showing increased risk of minor pathogens were seen in the corresponding right lower quadrant. Studies of moderate size were identified in the right middle of the plot, but substantially more moderately sized studies existed in the left middle. The Egger's test indicated evidence for small-study effects $(P=0.04)$ when only challenge studies were assessed. An attempt to impute estimates for types of studies that might be missing from the literature review (trim-and-fill method) resulted in no changes to the data (Steichen, 2000).

\section{DISCUSSION}

A wide variety of literature pertaining to minor and major mastitis pathogen interaction exists. The stud- ies selected for this meta-analysis, however, pertain specifically to minor pathogen IMI and its effects on the acquisition of major pathogen NIMI. During the literature search, several papers addressing questions of somatic cell count differences, duration of major pathogen infections in quarters previously or concomitantly infected with minor pathogens, morphological changes in the mammary gland after minor and major pathogen infections, and the effects of minor pathogens not specifically causing IMI (e.g., on teat apices) were also identified. Although research in these areas provides additional insight into the effects of minor pathogens in the bovine udder, these studies did not address the specific research question set for the analyses presented here. As such, these types of investigations and the information they contain can be used to augment work such as that presented here to provide further insight into the interactions between minor and major pathogens.

\section{Meta-Analyses}

It is emphasized again that, because of the large amount of heterogeneity among these studies, estimation of an overall effect of minor pathogens has limited utility. The meta-analyses presented here do suggest overall, however, that minor pathogens have a protective effect against NIMI with major pathogens. When broken down further, this effect was drawn from the results of challenge studies, as the result for observational studies was very close to the value for no effect and was not statistically significant (Table 2). Challenge studies, then, seem to show overwhelmingly more protection by minor pathogens, for reasons to be discussed below. Studies that could not be included in the meta-analysis because they did not report OR reported differing effects, with Spencer et al. (1968), Hogan et al. (1988), Woolford et al. (2001), and Zadoks et al. (2001a,b) all showing either an increase or no difference in the major pathogen infection in quarters infected with minor pathogens. The paper by Michel et al. (2011) describes greater prevalence of CNS in herds with lower prevalence of Staph. aureus, which might be inferred as protection by CNS against Staph. aureus.

The effects of the minor pathogens when separated were somewhat less clear. The CNS showed a strong protective effect against the major pathogens, whereas the protective effect was less pronounced, and did not achieve statistical significance, for C. bovis. As many authors have suggested, differences undoubtedly exist in the effects of the minor pathogens on the differing major pathogens, although this becomes more difficult to sort out because total numbers of studies for major pathogens other than Staph. aureus are low and, be- 
cause of this low power, analyses are unable to show differences beyond what might be attributed to chance.

Several protective mechanisms of minor pathogens have been investigated or suggested. Nonspecific activation of the immune system through host defense mechanisms such as increase in somatic cell count and differential cell count have been investigated and play a role in the interplay between pathogens in the bovine udder (Schukken et al., 1999; Pyörälä and Taponen, 2009). Production of bacteriocins and other inhibitory substances by minor pathogens have been suggested, as have stimulation of anti-staphylococcal antibody production by the host, alteration of fatty acid concentration, and general inhibition of major pathogen passage through the teat canal (Brooks and Barnum, 1984; Nickerson and Boddie, 1994; Schukken et al., 1999; Pyörälä and Taponen, 2009). These are all plausible explanations for the protection evidenced by the results presented here; however, it is beyond the scope of these analyses to suggest the reasons behind the protective effects or to lend credence to any particular theory.

\section{Underlying Risk}

Dohoo et al. (2007) have shown that, even with an underlying risk coefficient equal to -2 , the amount of bias in the outcome achieved by standard meta-analysis is limited. Because the recommended maximum likelihood random-slopes model gave coefficient estimates comparable to those given by standard meta-regression, this value was assumed to be accurate. Underlying risk accounted for a large amount of the heterogeneity among studies; its inclusion in a multivariable model resulted in an increase in the amount of heterogeneity explained by the model (e.g., adjusted- $\mathrm{R}^{2}$ increased from 58.0 to $81.7 \%$ ). Underlying risk may be a surrogate for the unmeasured factors contributing to variations in study populations (Dohoo et al., 2007), so its accounting for a significant proportion of the heterogeneity is not surprising. Although this paper sought to evaluate sources of heterogeneity among the included studies, many factors still remain unaccounted for.

\section{Meta-Regressions}

In unconditional associations (Table 1), the amount of heterogeneity accounted for by each of these predictors is substantial, with a total in excess of $100 \%$, as many of them are representing the same information (they are collinear). Because of this collinearity, many of the predictors that were significantly associated with the outcome in unconditional analyses could not be included in the multivariable model.
Although study design was not found to account for much of the between-study heterogeneity (adjusted- $\mathrm{R}^{2}$ $=7.8 \%$ ) in unconditional analysis, it was significant in the multivariable model, where both challenge-challenge and natural-challenge studies found more protection by minor pathogens than did observational studies. It has been noted that challenge studies often bypass the natural defenses of the teat (e.g., teat orifice, keratin plug) because pathogens are infused directly into the teat canal or teat cistern. In these studies, the majority of natural-challenge studies (8/9) had major pathogens administered directly into the teat, whereas among challenge-challenge studies administration was more varied ( 7 into the teat, 10 by immersion, and 9 that did not specify a route). The only challenge studies that identified minor pathogens as risk factors for major pathogen NIMI, however, were those that administered major pathogen via teat immersion. This was also found in unconditional analyses: studies infusing major pathogens into the teat (either by intracisternal injection or cannulation) identified minor pathogens as having much more of a protective effect than studies using teat immersion (OR decreased to 0.09 compared with no effect, $P<0.001$ ) or observational studies (OR decreased to 0.15 compared with no effect, $P<0.001$ ). This relationship also held true in the data subsets for CNS and all major pathogens (OR decreased to 0.05 compared with teat dip or observational studies, $P<$ 0.001 for both) and for CNS and Staph. aureus (OR decreased to 0.05 compared with teat dip, $P=0.007$; OR decreased to 0.03 compared with observational studies, $P=0.001$ ), but was borderline significant in the data subset for $C$. bovis and all major pathogens (OR for infused teats decreased to $0.18, P=0.05$; observational studies showed no difference, $P=0.23$ ) and completely nonsignificant in the data subset with $C$. bovis and $S$. aureus. This predictor alone represented $>87 \%$ of the heterogeneity among studies in both the CNS and $C$. bovis major pathogen data subsets.

It has been proposed that activity at the teat end makes the difference in penetration and eventual NIMI occurrence with major pathogens. Several authors have suggested that minor pathogens break down teat defenses or interfere with the keratin plug, allowing major pathogens to penetrate and initiate infection (Hogan et al., 1988; Williamson et al., 1995; Zadoks et al., 2001b; Berry and Hillerton, 2002a,b). It has also been shown that the presence of subclinical mastitis aids in the growth of major pathogens in the udder by the release of nutrients necessary for their survival (Mattila et al., 1984; Mattila and Sandholm, 1986; Kitt and Leigh, 1997). It may be that minor pathogens are protective against major pathogens once inside the ud- 
der, although they also may increase susceptibility to major pathogens accessing the udder tissue. If minor pathogens are indeed operating in different ways in different parts of the udder, this might explain why many challenge studies using infusion of major pathogens identify protection, whereas challenge studies using teat immersion and observational studies (in which major pathogens must access the udder via the teat end) often identify increased risk or no effect of minor pathogen IMI on acquisition of new major pathogen NIMI.

The protective effect of minor pathogen IMI on acquisition of a major pathogen NIMI was more likely to be seen in studies that utilized a more lenient definition of when an IMI exists or when a NIMI occurs. This was evident not only in IMI definitions in the larger data set but also in IMI threshold restrictions in the data subset with CNS and major pathogens. Stringent requirements for defining when an IMI exists or when a NIMI occurs mean that the specificity of diagnosis will be high, but at the cost of reduced sensitivity. Hence, although false positive diagnoses are minimized, false negative diagnoses will increase. Low sensitivity of bacteriological culture for the majority of pathogens has already been reported (Dohoo et al., 2011), and it is therefore possible that many of these studies underestimated the presence of minor pathogens and missed the occurrence of major pathogen NIMI. This misclassification bias undoubtedly affected the associations presented in these studies. Because the same sampling and bacteriological methods were applied to samples from cows with and without minor pathogen infection, it was assumed that the misclassification would be nondifferential and, therefore, that the associations would be biased toward the null, meaning they may, in fact, be underestimated.

Challenge studies utilizing higher doses of major pathogens for challenge and those that did not report the dosages used showed minor pathogen IMI to afford less protection against major pathogen NIMI. It is intuitive that a larger inoculum of major pathogen would more easily overcome any protective effect offered by minor pathogens, although this logic perhaps cannot be extended to studies that did not report the major pathogen dosage. Interestingly, studies without adequate descriptions of challenge protocols found more evidence for protection by minor pathogens than those with full descriptions of the protocols used. Many of these studies did not report significant details such as the route of challenge administration, method of allocation of quarters to be challenged, or the time between challenge and sampling for diagnosis of NIMI. Although inadequate reporting of details such as these does not necessarily mean that studies were not conducted appropriately, it does call into question the repeatability of the studies and the overall methods by which conclusions were reached.

The majority of studies either did not report the season in which they were conducted $(27 / 68)$ or were conducted over all 4 seasons $(39 / 68)$. Studies not reporting the season are likely to have been conducted over a short period (days or weeks instead of an entire year) and were more likely to find a protective effect of minor pathogens. Studies not reporting season were also associated with more frequent sampling of quarters. Although minor pathogens have been shown to cause chronic infections in the udder (HonkanenBuzalski et al., 1984; Pyörälä and Taponen, 2009), it may be that they exhibit more of a protective effect over a short period than over long periods. Another possible explanation is that studies conducted over long periods may culture minor pathogens at the beginning of the study period (before dry-off, for instance) instead of identifying these pathogens very close to the time of major pathogen NIMI.

Sampling frequency was closely related to study design but, like publication year, seemed to account for a greater proportion of the heterogeneity among studies (29.3 vs. $7.8 \%)$. It is difficult to attribute an observed effect of minor pathogen IMI on major pathogen NIMI to the presence of minor pathogen IMI cultured 10 to 20 wk before the occurrence of a NIMI, although this is what some manuscripts offered. Studies conducted over the dry period also identified minor pathogens before drying off and related their presence to the occurrence of major pathogen NIMI after calving, usually 6 or more weeks later. Minor pathogen infections may become chronic, but this cannot be assumed of all minor pathogen IMI during all stages of lactation, and conclusions from studies sampling over very long periods should be drawn with care.

\section{Publication Bias or Small-Study Effects}

The lack of studies showing high levels of risk caused by minor pathogen IMI may be an indication of publication bias (small studies showing increased risk of minor pathogens have not been published) or of small-study effects (smaller studies showed very protective effects of minor pathogens). In Figure 5, only 2 small studies showed very protective effects of minor pathogens, and 1 small observational study showed very protective effects (data not shown). Studies with moderate sample size and estimates of increased risk are included (right central area of the plot), although more moderately sized studies show protection (left central area). Approximately the same number of studies showed increased risk (right) in the upper portion of the plot compared with studies showing protection 
(left). If bias is present, however, and small or moderate studies showing increased risk of major pathogen NIMI caused by minor pathogens do exist, inclusion of these studies would serve to move the estimate of minor pathogen effect closer to the null. Another explanation is that the moderately sized studies showing protective effects are driving the estimate of effect toward protection. The studies represented in this middle left portion of the funnel plot ranged between 4 and 40 cows. Although this relationship was not evident in the univariable meta-regression with number of cows, this may be in part because the representation of number of cows was difficult and most closely approximated a quadratic relationship with the outcome. It can be seen in Figure 5, however, that the majority of small and moderate-sized studies showed a protective effect of minor pathogens. When studies were grouped according to number of cows $(\leq 40$ and $>40)$, those involving more cows were seen to show more risk for minor pathogens (OR increased to 6.0 compared with no effect, $P<$ 0.001 ) and $35.3 \%$ of the heterogeneity among studies was explained. This parameter could not be included in multivariable models, however, because it was collinear with study design.

Although it may not be possible to conduct experimental studies on large numbers of animals, smaller studies such as those reported here may suffer from a lack of rigorous scientific method. In the data presented here, all challenge studies judged to have inadequate protocols were studies with fewer than 40 cows. The 1 study that was judged to have inadequate time between pathogen challenge and subsequent diagnosis and the 2 studies that failed to describe this amount of time were also smaller studies. Moreover, smaller studies may not fully utilize the statistical tools available to account for occurrences such as interdependence, cow-level effects, or confounders. In thedata presented here, the 8 studies reporting estimates adjusted for risk factors other than minor pathogen infection were all $>40$ cows, as were all 6 studies in which multilevel modeling was used to account for interdependence between quarters, cows and herds.

Egger's test for small-study effects was significant for challenge studies, but not for observational studies. This is not surprising, because small-study effects were suspected on visual interpretation of the graph of challenge studies, and it is known that all tests proposed to evaluate small-study effects may give false positive results in the presence of extreme study heterogeneity (Harbord et al., 2009). The authors of the present study emphasize again that this excessive heterogeneity calls into question the accuracy of the estimate of effect given by the meta-analysis.

\section{Other Considerations}

To maximize power and detect significant differences in the meta-analyses and meta-regressions, the 2 groups of minor pathogens and several major pathogen groups were combined. Although this approach makes it possible to delineate differences that may not be seen with fewer data, it certainly has drawbacks, as it is not expected that these pathogens all behave in the same manner in nature. Certainly, speciation of the group of pathogens referred to as CNS would be beneficial, because different species exhibit a range of chronicity and inflammatory effects in the mammary gland (Supré et al., 2011). Some attempts to further examine the effects of individual minor pathogens on major pathogens were made but resulted in nonsignificant outcomes, most likely due to low power.

\section{CONCLUSIONS}

A wide body of evidence exists on the subject of minor pathogen IMI and its effect on the acquisition of major pathogen NIMI. Significant heterogeneity among studies exists, some of which could be accounted for using meta-regression. The analyses presented here reveal that, overall, challenge studies showed strong and significant protective effects, specifically when major pathogens were introduced into the mammary gland by methods that bypassed the teat end. Observational studies were not associated with either a protective effect or increased risk of major pathogen NIMI. Underlying risk can account for several unmeasured factors in studies and was significant in all challenge studies, revealing an inverse relationship with the outcome. Larger doses of challenge organisms reduced the protective effect of minor pathogens, and studies with more stringent diagnostic criteria for pathogen IMI also identified less protection. As the interval between infection with a minor pathogen and challenge with a major pathogen increased, less protection was identified. Studies in which samples were taken less frequently also demonstrated less protection, and smaller studies showed a greater protective effect than larger studies. The data suggest that, for several reasons, minor pathogens might seem more protective under artificial conditions than in realworld circumstances.

\section{ACKNOWLEDGMENTS}

Personal support for the primary author came from Atlantic Veterinary College's DVM Graduate Program Award (University of Prince Edward Island, Charlottetown, PEI, Canada) and National Sciences and Engi- 
neering Research Council's Canada Graduate Scholarship (Ontario, Canada).

\section{REFERENCES}

Aarestrup, F. M., and N. E. Jensen. 1997. Prevalence and duration of intramammary infection in Danish heifers during the peripartum period. J. Dairy Sci. 80:307-312.

Andersen, S., I. R. Dohoo, R. Olde Riekerink, and H. Stryhn., and Mastitis Research Workers' Conference. 2010. Diagnosing intramammary infections: Evaluating expert opinions on the definition of intramammary infection using conjoint analysis. J. Dairy Sci. 93:2966-2975.

Berry, E. A., and J. E. Hillerton. 2002a. The effect of selective dry cow treatment on new intramammary infections. J. Dairy Sci. 85:112-121.

Berry, E. A., and J. E. Hillerton. 2002b. The effect of an intramammary teat seal on new intramammary infections. J. Dairy Sci. $85: 2512-2520$

Black, R. T., C. T. Bourland, and R. T. Marshall. 1972. California mastitis test reactivity and bacterial invasions in quarters infected with Corynebacterium bovis. J. Dairy Sci. 55:1016-1017.

Bramley, A. J. 1975. Infection of the udder with coagulase negative micrococci and Corynebacterium bovis. Ann. Bull. Int. Dairy Fed. 85:377-381.

Bramley, A. J. 1976. Variations in the susceptibility of lactating and non-lactating bovine udders to infection when infused with Escherichia coli. J. Dairy Res. 43:205-211.

Bramley, A. J. 1978. The effect of subclinical Staphylococcus epidermidis infection of the lactating bovine udder on its susceptibility to infection with Streptococcus agalactiae or Escherichia coli. Br. Vet. J. 134:146-151.

Brooks, B. W., and D. A. Barnum. 1984. The susceptibility of bovine udder quarters colonized with Corynebacterium bovis to experimental infection with Staphylococcus aureus or Streptococcus agalactiae. Can. J. Comp. Med. 48:146-150.

Brooks, B. W., D. A. Barnum, and A. H. Meek. 1983. An observational study of Corynebacterium bovis in selected Ontario dairy herds. Can. J. Comp. Med. 47:73-78.

Davidson, T. J., I. R. Dohoo, A. W. Donald, H. Hariharan, and K. Collins. 1992. A cohort study of coagulase negative staphylococcal mastitis in selected dairy herds in Prince Edward Island. Can. J. Vet. Res. 56:275-280.

DerSimonian, R., and N. Laird. 1986. Meta-analysis in clinical trials. Control. Clin. Trials 7:177-188.

Doane, R. M., S. P. Oliver, R. D. Walker, and E. P. Shull. 1987. Experimental infection of lactating bovine mammary glands with Streptococcus uberis in quarters colonized by Corynebacterium bovis. Am. J. Vet. Res. 48:749-754.

Dohoo, I. R., J. Smith, S. Andersen, D. F. Kelton, and S. Godden 2011. Diagnosing intramammary infections: Evaluations based on a single milk sample. J. Dairy Sci. 94:250-261.

Dohoo, I. R., H. Stryhn, and J. Sanchez. 2007. Evaluation of underlying risk as a source of heterogeneity in meta-analysis: A simulation study of Bayesian and frequentist implementations of three models. Prev. Vet. Med. 81:38-55.

Green, M. J., L. E. Green, A. J. Bradley, P. R. Burton, Y. H. Schukken, and G. F. Medley. 2005. Prevalence and associations between bacterial isolates from dry mammary glands of dairy cows. Vet. Rec. 156:71-77.

Green, M. J., L. E. Green, G. F. Medley, Y. H. Schukken, and A. J Bradley. 2002. Influence of dry period bacterial intramammary infection on clinical mastitis in dairy cows. J. Dairy Sci. 85:25892599.

Harbord, R. M., R. J. Harris, and J. A. C. Sterne. 2009. Updated test for small-study effects in meta analyses. Stata J. 9:197-210.

Harbord, R. M., and J. P. T. Higgins. 2008. Meta-regression in Stata. Stata J. 8:493-519.
Hogan, J. S., K. L. Smith, D. A. Todhunter, and P. S. Schoenberger. 1988. Rate of environmental mastitis in quarters infected with Corynebacterium bovis and Staphylococcus species. J. Dairy Sci. $71: 2520-2525$.

Honkanen-Buzalski, T., T. K. Griffin, and F. H. Dodd. 1984. Observations on Corynebacterium bovis infection of the bovine mammary gland. I. Natural infection. J. Dairy Res. 51:371-378.

Kitt, A. J., and J. A. Leigh. 1997. The auxotrophic nature of Streptococcus uberis - The acquisition of essential amino acids from plasmin derived casein peptides. Adv. Exp. Med. Biol. 418:647-650.

Lam, T. J., Y. H. Schukken, J. H. van Vliet, F. J. Grommers, M. J. Tielen, and A. Brand. 1997. Effect of natural infection with minor pathogens on susceptibility to natural infection with major pathogens in the bovine mammary gland. Am. J. Vet. Res. 58:17-22.

Linde, C. 1982. The effect of coagulase-negative staphylococci in the cow's udder on experimental induction of mastitis and on milk production. PhD Thesis. Swedish University of Agricultural Sciences, Uppsala, Sweden.

Linde, C., O. Holmberg, and G. Astrom. 1975a. An attempt to superimpose Staphylococcus aureus, Streptococcus agalactiae and Streptococcus dysgalactiae upon Staphylococcus epidermidis infections in the cow's udder. Ann. Bull. Int. Dairy Fed. 85:391-394.

Linde, C., O. Holmberg, and G. Astrom. 1975b. Interference between Staphylococcus epidermidis (Se) and Staphylococcus aureus (Sa) in the bovine udder. Acta Vet. Scand. 16:146-148.

Linde, C., O. Holmberg, and G. Astrom. 1976. Interference between Staphylococcus epidermidis and more pathogenic bacteria in the bovine udder. Zentralbl. Bakteriol. 5(Suppl. 5):1035-1039.

Linde, C., O. Holmberg, and G. Astrom. 1980. The interference between coagulase negative staphylococci and Corynebacterium bovis and the common udder pathogens in the lactating cow. Nord. Vet. Med. 32:552-558.

Matthews, K. R., R. J. Harmon, and B. E. Langlois. 1991. Effect of naturally occurring coagulase negative staphylococci infections on new infections by mastitis pathogens in the bovine. J. Dairy Sci. 74:1855-1859.

Matthews, K. R., R. J. Harmon, and B. A. Smith. 1990. Protective effect of Staphylococcus chromogenes infection against Staphylococcus aureus infection in the lactating bovine mammary gland. J. Dairy Sci. 73:3457-3462.

Mattila, T., and M. Sandholm. 1986. Milk plasmin, $N$-acetyl-P-D-glucosaminidase and antitrypsin as determinants of bacterial replication rates in whey. J. Dairy Sci. 69:670-675.

Mattila, T., J. Syväjäri, and M. Sandholm. 1984. Bacterial growth in whey from mastitic and nonmastitic quarters. Am. J. Vet. Res. 45:2504-2506.

Michel, A., C. Syring, A. Steiner, and H. U. Graber. 2011. Intramammary infections with the contagious Staphylococcus aureus genotype B in Swiss dairy cows are associated with low prevalence of coagulase-negative staphylococci and Streptococcus spp. Vet. J. 188:313-317.

Myllys, V. 1995. Staphylococci in heifer mastitis before and after parturition. J. Dairy Res. 62:51-60.

Newbould, F. H. S., and F. K. Neave. 1965. The recovery of small numbers of Staphylococcus aureus infused into the bovine teat cistern. J. Dairy Res. 32:157-162.

Nickerson, S. C., and R. L. Boddie. 1994. Effect of naturally occurring coagulase-negative staphylococcal infections on experimental challenge with major mastitis pathogens. J. Dairy Sci. 77:2526-2536.

Pankey, J. W., S. C. Nickerson, R. L. Boddie, and J. S. Hogan. 1985 Effects of Corynebacterium bovis infection on susceptibility to major mastitis pathogens. J. Dairy Sci. 68:2684-2693.

Parker, K. I., C. Compton, F. M. Anniss, A. Weir, C. Heuer, and S. McDougall. 2007. Subclinical and clinical mastitis in heifers following the use of a teat sealant precalving. J. Dairy Sci. 90:207-218.

Postle, D. S., M. Roguinsky, and B. Poutrel. 1978. Induced staphylococcal infections in the bovine mammary gland. Am. J. Vet. Res. 39:29-35.

Poutrel, B., and C. Lerondelle. 1980. Protective effect in the lactating bovine mammary gland induced by coagulase-negative staphylo- 
cocci against experimental Staphylococcus aureus infections. Ann. Rech. Vet. 11:327-332.

Pyörälä, S., H. Simojoki, and S. Taponen. 2011. News about mastitiscausing staphylococci. Pages 93-104 in Proc. of European Buiatrics Forum. R. Maillard and H. Navetat, ed. Société Française de Buiatrie, Labastide-Saint-Pierre, France.

Pyörälä, S., and S. Taponen. 2009. Coagulase-negative staphylococciEmerging mastitis pathogens. Vet. Microbiol. 134:3-8.

Rainard, P., and B. Poutrel. 1988. Effect of naturally occurring intramammary infections by minor pathogens on new infections by major pathogens in cattle. Am. J. Vet. Res. 49:327-329.

Reyher, K. K., I. R. Dohoo, D. T. Scholl, and G. P. Keefe. 2012. Evaluation of minor pathogen intramammary infection, susceptibility parameters and somatic cell counts on the development of new intramammary infections with major mastitis pathogens. J. Dairy Sci. 95:3766-3780.

Sargeant, J. M., A. Rajic, S. Read, and A. Ohlsson. 2006. The process of systematic review and its application in agri-food public health. Prev. Vet. Med. 75:141-151.

Schukken, Y. H., K. E. Leslie, D. A. Barnum, B. A. Mallard, J. H. Lumsden, P. C. Dick, G. H. Vessie, and M. E. Kehrli. 1999. Experimental Staphylococcus aureus intramammary challenge in late lactation dairy cows: Quarter and cow effects determining the probability of infection. J. Dairy Sci. 82:2393-2401.

Spencer, G. R., D. M. Fluharty, and B. Newman. 1968. Staphylococci of different virulences infused successively into bovine udders. Pathol. Vet. 5:7-25.
Steichen, T. J. 2000. Nonparametric trim and fill analysis of publication bias in meta-analysis. Stata Tech. Bull. 57:8-14.

Supré, K., F. Haesebrouck, R. N. Zadoks, M. Vaneechoutte, S. Piepers, and S. De Vleigher. 2011. Some coagulase-negative Staphylococcus species affect udder health more than others. J. Dairy Sci. 94:2329-2340

Sweeting, M. J., A. J. Sutton, and P. C. Lambert. 2004. What to add to nothing? Use and avoidance of continuity corrections in metaanalysis data. Stat. Med. 23:1351-1375.

Williamson, J. H., M. W. Woolford, and A. M. Day. 1995. The prophylactic effect of a dry cow antibiotic against Streptococcus uberis. N. Z. Vet. J. 43:228-234

Woolford, M. W., J. H. Williamson, T. M. Day, S. J. Lacy-Hulbert, and H. V. Henderson. 2001. Effect of localised antibiotic infusions applied to the teat-canal and teat sinus at drying-off on mastitis in the dry-period and at calving. J. Dairy Res. 68:551-558.

Zadoks, R. N., H. G. Allore, H. W. Barkema, O. C. Sampimon, Y. T. Grohn, and Y. H. Schukken. 2001a. Analysis of an outbreak of Streptococcus uberis mastitis. J. Dairy Sci. 84:590-599.

Zadoks, R. N., H. G. Allore, H. W. Barkema, O. C. Sampimon, G. J. Wellenberg, Y. T. Grohn, and Y. H. Schukken. 2001b. Cow- and quarter-level risk factors for Streptococcus uberis and Staphylococcus aureus mastitis. J. Dairy Sci. 84:2649-2663.

\section{APPENDIX}

Table A1. Overview and descriptive information of 38 manuscripts comprising 68 studies used in meta-analyses examining the effect of minor pathogen IMI on new IMI with major pathogens

\begin{tabular}{|c|c|c|c|c|c|c|}
\hline Reference/study number & $\begin{array}{l}\text { Study } \\
\text { design }^{1}\end{array}$ & $\begin{array}{l}\text { Minor } \\
\text { pathogens }\end{array}$ & Major pathogens ${ }^{3}$ & $\begin{array}{c}\text { No. of } \\
\text { cows }\end{array}$ & Parity $^{4}$ & Stage $^{5}$ \\
\hline Aarestrup and Jensen (1997) & $\mathrm{O}$ & CNS & SA, SU, SD & 180 & $\mathrm{H}$ & Lact \\
\hline Berry and Hillerton (2002a) $\mathrm{I}^{6}$ & $\mathrm{O}$ & CNS & $\mathrm{SA}, \mathrm{SU}$, coli & 290 & ND & Dry \\
\hline Berry and Hillerton (2002b) I & $\mathrm{O}$ & CNS & SA, SU, coli & 401 & ND & Dry \\
\hline Berry and Hillerton (2002b) II & $\mathrm{O}$ & $\mathrm{CB}$ & SA, SU, coli & 401 & ND & Dry \\
\hline Black et al. (1972) I & $\mathrm{O}$ & $\mathrm{CB}$ & SA & 32 & ND & Lact \\
\hline Black et al. (1972) IV & $\mathrm{O}$ & $\mathrm{CB}$ & coli, oth & 38 & ND & Lact \\
\hline Black et al. (1972) V & $\mathrm{O}$ & $\mathrm{CB}$ & $\mathrm{SA}$ & 38 & ND & Lact \\
\hline Black et al. (1972) VI & $\mathrm{O}$ & $\mathrm{CB}$ & SAg, SU, SD, oth & 38 & ND & Lact \\
\hline Bramley (1975) & $\mathrm{O}$ & $\mathrm{CB}$ & $\mathrm{SA}, \mathrm{SAg}, \mathrm{SU}, \mathrm{SD}$, coli & $\mathrm{ND}^{7}$ & ND & Both \\
\hline Bramley (1976) I & $\mathrm{NC}$ & CNS & coli & 6 & $\mathrm{H}+\mathrm{L}$ & Lact \\
\hline Bramley (1976) II & $\mathrm{NC}$ & $\mathrm{CNS}$ & coli & 4 & $\mathrm{H}+\mathrm{L}$ & Dry \\
\hline Bramley (1978) & $\mathrm{CC}$ & CNS & $\mathrm{SAg}$, coli & 17 & ND & Lact \\
\hline Davidson et al. (1992) & $\mathrm{O}$ & CNS & $\mathrm{SA}$ & 84 & $\mathrm{~L}$ & Lact \\
\hline Doane et al. (1987) I & $\mathrm{NC}$ & $\mathrm{CB}$ & SU & 18 & ND & Lact \\
\hline Doane et al. (1987) II & $\mathrm{NC}$ & $\mathrm{CB}$ & $\mathrm{SU}$ & 4 & ND & Lact \\
\hline Green et al. (2002) I & $\mathrm{O}$ & $\mathrm{CB}$ & SA, SAg, SU, SD, coli, oth & 480 & ND & Both \\
\hline Green et al. (2002) II & $\mathrm{O}$ & $\mathrm{CB}$ & SA, SAg, SU, SD, coli, oth & 480 & ND & Both \\
\hline Green et al. (2005) I & $\mathrm{O}$ & $\mathrm{CNS}$ & SA & 480 & ND & Dry \\
\hline Green et al. (2005) II & $\mathrm{O}$ & $\mathrm{CB}$ & SA & 480 & ND & Dry \\
\hline Green et al. (2005) III & $\mathrm{O}$ & $\mathrm{CB}$ & $\mathrm{SU}$ & 480 & ND & Dry \\
\hline Honkanen-Buzalski et al. (1984) I & $\mathrm{O}$ & $\mathrm{CB}$ & SA, SAg, SU, SD, coli, oth & 1,450 & ND & Both \\
\hline Honkanen-Buzalski et al. (1984) II & $\mathrm{O}$ & $\mathrm{CB}$ & SA, SAg, SU, SD, coli, oth & 1,450 & ND & Both \\
\hline Lam et al. (1997) I & $\mathrm{O}$ & CNS & SA, SU, SD, coli & 392 & ND & Both \\
\hline Lam et al. (1997) II & $\mathrm{O}$ & $\mathrm{CB}$ & $\mathrm{SA}, \mathrm{SU}, \mathrm{SD}$, coli & 392 & ND & Both \\
\hline Linde et al. (1975a) & $\mathrm{CC}$ & CNS & $\mathrm{SA}$ & 9 & ND & Lact \\
\hline
\end{tabular}


Table A1 (Continued). Overview and descriptive information of 38 manuscripts comprising 68 studies used in meta-analyses examining the effect of minor pathogen IMI on new IMI with major pathogens

\begin{tabular}{|c|c|c|c|c|c|c|}
\hline Reference/study number & $\begin{array}{l}\text { Study } \\
\text { design }{ }^{1}\end{array}$ & $\begin{array}{l}\text { Minor } \\
\text { pathogens }^{2}\end{array}$ & Major pathogens ${ }^{3}$ & $\begin{array}{c}\text { No. of } \\
\text { cows }\end{array}$ & Parity $^{4}$ & Stage ${ }^{5}$ \\
\hline Linde et al. (1975b) I & $\mathrm{CC}$ & CNS & $\mathrm{SA}, \mathrm{SAg}, \mathrm{SD}$ & 14 & ND & Lact \\
\hline Linde et al. (1975b) II & $\mathrm{CC}$ & CNS & $\mathrm{SAg}, \mathrm{SD}$ & 5 & ND & Lact \\
\hline Linde et al. (1976) II & $\mathrm{CC}$ & CNS & $\mathrm{SAg}, \mathrm{SU}, \mathrm{SD}$ & 7 & ND & Lact \\
\hline Linde et al. (1980) I & $\mathrm{CC}$ & CNS & $\mathrm{SA}$ & 8 & ND & Lact \\
\hline Linde et al. (1980) II & $\mathrm{CC}$ & $\mathrm{CNS}$ & SAg, SU, SD & 7 & ND & Lact \\
\hline Linde (1982) II & $\mathrm{CC}$ & $\mathrm{CNS}$ & $\mathrm{SAg}, \mathrm{SU}, \mathrm{SD}$ & 7 & ND & Lact \\
\hline Linde (1982) III & $\mathrm{CC}$ & $\mathrm{CNS}$ & Coli, oth & 9 & ND & Lact \\
\hline Matthews et al. (1990) & $\mathrm{NC}$ & CNS & SA & 10 & ND & Lact \\
\hline Matthews et al. (1991) & $\mathrm{O}$ & CNS & SA, SU, SD, coli, oth & 113 & $\mathrm{H}+\mathrm{L}$ & Both \\
\hline Myllys (1995) & $\mathrm{O}$ & CNS & $\mathrm{SA}, \mathrm{SU}, \mathrm{SD}$, oth & 50 & $\mathrm{H}$ & Dry \\
\hline Newbould and Neave (1965) & $\mathrm{NC}$ & $\mathrm{CB}$ & SA & 10 & $\mathrm{H}+\mathrm{L}$ & Lact \\
\hline Pankey et al. (1985) V & $\mathrm{CC}$ & $\mathrm{CB}$ & SA & ND & ND & Lact \\
\hline Pankey et al. (1985) VI & $\mathrm{CC}$ & CNS & SA & ND & ND & Lact \\
\hline Pankey et al. (1985) VII & $\mathrm{CC}$ & $\mathrm{CB}$ & $\mathrm{SAg}$ & ND & ND & Lact \\
\hline Pankey et al. (1985) VIII & $\mathrm{CC}$ & $\mathrm{CNS}$ & $\mathrm{SAg}$ & ND & ND & Lact \\
\hline Pankey et al. (1985) IX & $\mathrm{CC}$ & $\mathrm{CB}$ & $\mathrm{SAg}$ & ND & ND & Lact \\
\hline Pankey et al. (1985) X & $\mathrm{CC}$ & CNS & $\mathrm{SAg}$ & ND & ND & Lact \\
\hline Pankey et al. (1985) XI & $\mathrm{O}$ & $\mathrm{CB}$ & $\mathrm{SU}$ & ND & ND & Dry \\
\hline Parker et al. (2007) & $\mathrm{O}$ & CNS & SA, SU, SD, coli, oth & 255 & $\mathrm{H}$ & Dry \\
\hline Postle et al. (1978) & $\mathrm{NC}$ & $\mathrm{CB}$ & $\mathrm{SA}$ & 41 & $\mathrm{H}+\mathrm{L}$ & Lact \\
\hline Poutrel and Lerondelle (1980) & $\mathrm{CC}$ & $\mathrm{CNS}$ & $\mathrm{SA}$ & 44 & $\mathrm{H}$ & Lact \\
\hline Rainard and Poutrel (1988) I & $\mathrm{O}$ & CNS & $\mathrm{SA}, \mathrm{SAg}, \mathrm{SU}, \mathrm{SD}$ & 122 & $\mathrm{H}+\mathrm{L}$ & Lact \\
\hline Rainard and Poutrel (1988) II & $\mathrm{O}$ & $\mathrm{CB}$ & SA, SAg, SU, SD & 122 & $\mathrm{H}+\mathrm{L}$ & Lact \\
\hline Reyher et al. (2012) I & $\mathrm{O}$ & CNS & SA, SU, SD, coli & 6,825 & $\mathrm{H}+\mathrm{L}$ & Lact \\
\hline Reyher et al. (2012) II & $\mathrm{O}$ & $\mathrm{CB}$ & SA, SU, SD, coli & 6,825 & $\mathrm{H}+\mathrm{L}$ & Lact \\
\hline
\end{tabular}

${ }^{1}$ Study design: $\mathrm{O}=$ observational, $\mathrm{CC}=$ challenge studies where quarters were experimentally challenged both with a minor pathogen and subsequently with a major pathogen, $\mathrm{NC}=$ challenge studies where quarters were naturally infected with a minor pathogen and challenged with a major pathogen.

${ }^{2}$ Minor pathogens represented: CNS, Corynebacterium bovis (CB).

${ }^{3}$ Major pathogens represented: Staphylococcus aureus (SA); Streptococcus agalactiae (SAg); Streptococcus uberis (SU); Streptococcus dysgalactiae (SD); coliforms (coli); other streptococci, Pseudomonas spp., yeast (oth).

${ }^{4}$ Parity: $\mathrm{H}=$ heifers only, $\mathrm{L}=$ lactating cows only, $\mathrm{H}+\mathrm{L}=$ heifers and lactating cows, $\mathrm{ND}=$ not described.

${ }^{5}$ Stage of lactation: lact $=$ lactation only, dry $=$ dry period only, both $=$ both lactation and dry period.

${ }^{6}$ Study number from a single reference.

${ }^{7}$ Not described. 